\title{
Evaluation of Biorational Insecticides as Stand-alone Treatments for the Management of the Pigweed Flea Beetle, Disonycha glabrata (Coleoptera: Chrysomelidae), in Organic Production of Amaranthus spp.
}

\author{
Roger V. Vorsah ${ }^{1}$, Beatrice N. Dingha ${ }^{1}$, Harmandeep Sharma ${ }^{1} \&$ Louis E. Jackai $^{1}$ \\ ${ }^{1}$ Department of Natural Resources and Environmental Design, North Carolina Agricultural \& Technical State \\ University, Greensboro, NC 27411, USA \\ Correspondence: Louis E. Jackai, Department of Natural Resources and Environmental Design, North Carolina \\ Agricultural \& Technical State University, Greensboro, NC 27411, USA. Tel: 1-336-285-4837. E-mail: \\ lejackai@ncat.edu
}

Received: March 31, 2020

Accepted: May 8, 2020 Online Published: May 26, 2020

doi:10.5539/sar.v9n3p58

URL: https://doi.org/10.5539/sar.v9n3p58

\begin{abstract}
The pigweed flea beetle, Disonycha glabrata, is the most damaging insect pest on Amaranthus spp. in the Piedmont zone of North Carolina (NC), United States. It is capable of causing severe yield loss on amaranth greens if uncontrolled. Field experiments were conducted over two growing seasons (Summer 2017 and 2018) in Greensboro, NC, to evaluate OMRI-approved biorational insecticides against D. glabrata in organic amaranth production. Insecticides evaluated included Azatin ${ }^{\circledR} \mathrm{O}$ (azadiractin), Ecotec ${ }^{\circledR}$ (oils: rosemary, peppermint and geraniol), Entrust ${ }^{\circledR}$ (spinosad) and PyGanic ${ }^{\circledR}$ (pyrethrins) as stand-alone threshold-driven treatments applied at recommended label rates. Insecticide treatment action threshold (AT) was 2 (on a scale of 5) representing 20-40\% leaf damage. The efficacy of the insecticides against $D$. glabrata population differed significantly within the amaranth varieties in comparison to their respective controls: treatments with Entrust ${ }^{\circledR}$ and PyGanic ${ }^{\circledR}$ on Green Callaloo and Red Leaf recorded $80 \%$ reduction in beetle population while Ecotec ${ }^{\circledR}$ gave only a $15 \%$ beetle reduction. The Azatin ${ }^{\circledR} \mathrm{O}$ treatments recorded the highest $D$. glabrata population, sometimes greater than the control. Marketable fresh leaf yield from both Green Callaloo and Red Leaf amaranth was highest in the Entrust $^{\circledR}$ and PyGanic ${ }^{\circledR}$ treatments. Hopi Red-Dye and Molten Fire amaranths showed some resistance to beetle damage; they are also intrinsically low yielding. These findings provide information that would make organic amaranth production possible with only limited and safe insecticide input using OMRI-approved insecticides in a threshold-driven manner, an important step towards the sustainable management of D. glabrata and amaranth production.
\end{abstract}

Keywords: Amaranthus spp., biorational insecticides, Disonycha glabrata, OMRI-approved, organic

\section{Introduction}

Amaranthus spp. (commonly known as pigweed in the USA) are underexploited and underutilized annuals or short-lived perennials with over sixty species and approximately six thousand varieties with only a few of them (Amaranthus hypochondriacus, A. caudatus, A. cruentus, A. retroflexus inter alia) cultivated for food world-wide (Brenner et al., 2000). Amaranth is one of three most important "pseudocereals" of worldwide importance which are cultivated either for their tender leaves, young whole plants or for grain (Janssen et al., 2017). The plant is rich in minerals, vitamins, proteins, antioxidants and is gluten-free, making it a perfect choice in overcoming many health-related disorders in humans (Ezeh, Ogbedegbe, \& Ogbedegbe, 2015). It also has the potential as a biofuel feedstock (Viglasky, Huska, Langova, \& Suchomel, 2008; Xaba, 2014). Specialty vegetables such as Amaranthus spp. and quinoa (Chenopodium quinoa),also in the Amarathaceae family, have gained rapid acceptance among small growers in the state of North Carolina (NC) as demand for them increases, especially among immigrants and other individuals, especially those who are health conscious (Brenner et al., 2000; Vorsah et al., 2020).

Insect pests of economic importance to Amaranthus spp. are predominantly in the orders Coleoptera, Lepidoptera, Hemiptera and Diptera (Niveyro, Mortensen, Fomsgaard, \& Salvo, 2013; Ezeh et al., 2015). In the 
USA, and specifically North Carolina, the pigweed flea beetle, Disonycha glabrata (Coleoptera: Chrysomelidae), is a key amaranth pest (Vorsah et al., 2020). D. glabrata feeds on the lower leaf surface leaving the veins intact thus creating a skeletonized appearance of the leaf blade (Blake, 1933; Blake, 1955; Tisler, 1990; Vorsah et al., 2020). This feeding pattern increases susceptibility in young amaranth plants resulting in growth retardation and plant death linked to a decrease in chlorophyll content and desiccation (Hemenway \& Whitcomb, 1968; Vorsah et al., 2020). The outcome includes loss of yield and income since most consumers demand undamaged leaves. In some cases, to mitigate losses growers use synthetic insecticides as the management tactic of choice to control pests such as the lepidopteran defoliator, Spoladea recurvalis, Fab. (Family: Crambidae) often with varying level of success (Sufang et al., 2013; Iwuagwu, Ogbonna, \& Okechukwu, 2019; Muralikrishna, Mathew, Paul, \& Nithya, 2019). However, the use of synthetic insecticides as a plant protection measure not only remains controversial but is also highly restricted in organic production of leafy and other vegetables. This is in part due to high and acute residual toxicity and long periods of persistence of some chemicals, resulting in pesticide residue in food, pest resurgence and resistance in pest populations among other concerns (Sufang et al., 2013; Baker et al., 2015; Organic Trade Association (OTA), 2015). This situation calls for a more sustainable pest management approach that takes into consideration how the crop is consumed. In the case of amaranths this entails minimal processing (i.e. washing) prior to cooking or in salads (Rastogi \& Shukla, 2013). Biorational insecticides provide of a safer, effective and sustainable insect pest management plan for organic production of amaranth as it leaves minimal negative footprints in the ecosystem (Korrat, Abdelmonem, Helalia, \& Khalifa, 2012; Sufang et al., 2013; Iwuagwu et al. 2019). Biorational insecticides obtained from leaves and flowers (e.g. Azardirachta indica, Jatropha curca, chrysanthemums spp.) and microbes (e.g. Saccharopolyspora spinosa, Bacillus thuringiensis) are known to be effective in the management of insect pests on leafy vegetables, including lepidopteran defoliators on Amaranthus spp. (Cordero, Kuhar, Speese, \& Barlow, 2005; Nuessly, 2005; Flanery, Sintim, Dingha, \& Jackai, 2016; Iwuagwu et al. 2019; Muralikrishna et al., 2019). Given their range of activity across insect taxa, we there is a good chance that biorational insecticides hold great promise for management of $D$. glabrata. We therefore wanted to investigate the efficacy of a number of commonly available biorational insecticides in the management of D. glabrata in a field study using four Amaranthus varieties, both on the pest population directly and also on fresh leaf yield. Rather than use conventional calendar treatments as is often the case, we used a predetermined treatment threshold that will regulate their use based on the level of damage on the crop (Vorsah et al., 2020); this will reduce both the overall pesticide load on the crop and also minimize the cost of control efforts.

\section{Method}

\subsection{Field Experimental Design}

The study was conducted at the Research Farm in North Carolina Agricultural \& Technical State University (NCA\&TSU) (longitude $36.05^{\circ} \mathrm{N}$ and latitude $79.71^{\circ} \mathrm{W}$ ) in Greensboro, NC. The experiment was set up in a randomized complete block design (RCBD) with four replicates, each measuring $27 \mathrm{~m} \mathrm{x} 11 \mathrm{~m}$ and separated from each other by a $3 \mathrm{~m}$ unplanted buffer. Four amaranth varieties were used in the study: Green Callaloo and Molten Fire were used in 2017 while Green Callaloo, Red Leaf, Molten Fire and Hopi Red-Dye were used in 2018. These varieties were selected based on their susceptibility to damage by $D$. glabrata; the first two varieties being highly susceptible and the latter somewhat resistant (Vorsah et al., 2020). Amaranth seeds were purchased from Johnny's Selected Seeds (Winslow, ME), Stoke Seeds Ltd. (Thorold, ON, Canada) and Baker Creek Heirloom Seed (Mansfield, MO, USA). A custom-formulated soil mixture (used in Guilford College Organic Farm, NC) [i.e. twenty-two scoops $\left(500 \mathrm{~mL}\right.$ cup) of Sungro $^{\circledR}$ Professional Growing Mix soil (Sun Gro Horticulture, MA), nine scoops (500 mL cup) of compost (White Street Landfill, NC), four scoops of red soil (500 mL cup) and one-eighth of $150 \mathrm{~mL}$ cup of Down-To-Earth ${ }^{\circledR}$ Feather Meal (N-P-K, 12-0-0) (formulation of dried and ground poultry feathers containing 12\% nitrogen) (Down To Earth Distributors Inc., Eugene, OR)] was used for sowing the seeds in a greenhouse under natural light conditions on 2 May in seventy-two-cell seed trays $(54 \times 29 \times 6 \mathrm{~cm})$, three seeds per cell. Temperature was maintained between $18{ }^{\circ} \mathrm{C}$ and $24{ }^{\circ} \mathrm{C}$ and relative humidity between $70 \%$ and $80 \%$. Germination was observed six to eight days after sowing (DAS). At 10 DAS, seedlings were transferred one plant per cell into thirty-six-cell seed trays $(27 \times 15 \times 6 \mathrm{~cm})$ to avoid overcrowding as well as ensure optimum plant growth. Each variety was transplanted in the field on June 8 and 11 in 2017 and 2018, respectively, on two row plots of each measuring $4 \mathrm{~m}$ x $1.5 \mathrm{~m}$ separated by a $2 \mathrm{~m}$ buffer and $1.5 \mathrm{~m}$ apart between insecticide treatments. Planting density was 8 plants per $4 \mathrm{~m}$ row at a within-row plant distance of $0.5 \mathrm{~m}$. Prior to transplanting, wheat straw mulch (Rankin Farms Inc., Elllerbe, NC) was laid on the plots to manage weeds and conserve moisture. Drip irrigation was provided as needed. During transplanting, 3 $\mathrm{mL}$ cup of organic material research institute (OMRI)-certified all-natural composted poultry layer manure, 
Harmony ${ }^{\circledR}$ Ag Organic fertilizer (N-P-K, 5-4-3 with 9\% Ca) (Environmental Products LLC, Roanoke, VA) was added to the soil. Any required weeding was done manually.

\subsection{Insecticide Application, D. glabrata Sampling and Damage Rating}

Four Organic Materials Review Institute (OMRI)-approved insecticides namely, Azatin ${ }^{\circledR} \mathrm{O}$ (Azadirachtin 2.5\%; OHP, Inc., Mainland, PA), PyGanic ${ }^{\circledR}$ (Pyrethrin 1.4\%; MGK, Minneapolis, MN), Entrust ${ }^{\circledR}$ SC (Spinosad 22.5\%; Dow AgroSciences LLC, Indianapolis, IN) and Brandt ${ }^{\circledR}$ Ecotec $^{\circledR}$ Plus ${ }^{\circledR}$ (rosemary oil 10.0\%, geraniol 5.0\% and peppermint Oil 2.0\%; Brandt Consolidated Inc., Springfield, IL) were evaluated for their efficacy in the control of D. glabrata and the associated herbivory as stand-alone treatments. In addition, a water spray was included as a control. Choice of insecticides was advised by results from unpublished preliminary field experiments which indicated that a single-use of some of these products provided remarkable results. During both 2017 and 2018 seasons foliar applications of the insecticides were made with a pressured hand-operated 4-gallon backpack sprayer (Solo ${ }^{\circledR}$, Newport News, VA) calibrated to deliver 411.50 Lha-1 at $1810.02-2068.59 \mathrm{mmHg}$. Application rates were based on recommended label rates: (i) PyGanic ${ }^{\circledR}: 62.7$ gaih $^{-1}$, (ii) Azatin ${ }^{\circledR}$ O: 50.4 gaih $^{-1}$, (iii) Entrust ${ }^{\circledR}$ SC: 126.0 gaih $^{-1,}$ and (iv) Brandt ${ }^{\circledR}$ Ecotec $^{\circledast}$ Plus $^{\circledR}: 71.4$ gaih $^{-1}$. To avoid unnecessary treatments, the insecticides were applied only if a preset action threshold (AT) score of $\geq 2$ signifying $20-40 \%$ leaf damage was attained in 50 percent or more of the replications.

Leaf damage due to beetle feeding was estimated by direct observation in the field at pre- and post- insecticide application using a damage score of $1-5$ (where $1=0-20 \%, 2=>20-40 \%, 3=>40-60 \%, 4=>60-80 \%$ and $5=>80-100 \%$ leaf damage) described by Vorsah et al. (2020) on five fully expanded leaves at the crown of each of eight plants on the same row. To avoid sampling previously sampled leaves, a notch was made on the margins of sampled leaves. This ensured that we sampled only newly opened leaves (that were generally the preferred feeding site) on subsequent weekly sampling dates.

The population of D. glabrata at pre- and post- insecticide application was estimated using a reversed leaf blower as described by Vorsah et al. (2020); beetles were sampled for 30 seconds per 4 m-row, between 9 am to 12 pm, weekly from 3 July to 4 September in both 2017 and 2018. All samples were transferred into labelled Ziploc $^{\circledR}$ bags and taken to the Integrated Pest Management (IPM) laboratory at NCA\&TSU where they were identified under magnification (AmScope Stereozoom trinocular microscope, SZMT2 Series, WF10X/20; United Scope LLC, Irvine, CA).

\subsection{Amaranth Leaf Yield}

Fresh amaranth leaves together with the subtending bouquet stems were harvested at 2-week intervals using a hand-held pruner (2.4" x 1.3" x 8.5" Model: F2; The Home Depot ${ }^{\circledR}$, USA) between 24 July (46 days after transplanting [DAT]) to 21 August (74 DAT) in 2017 and between 24 July (43 DAT) to 28 August (78 DAT) in 2018. Harvested leaves were weighed using an Ohaus T51P scale (Pine Brook, NJ, USA).

\subsection{Data Analysis}

This study was conducted as a randomized complete block design (RCBD). For each season, the number of sprays, the mean number of D. glabrata adults, the mean damage rating and fresh leaf yield were evaluated for each insecticide treatment. One-way and two-way analysis of variance (ANOVA) (PROC GLM) was used to evaluate the effects of insecticide treatments on D. glabrata populations, leaf damage, and harvestable yield in 2017 and 2018, respectively. Means were separated using Fisher's least significant difference (LSD) at 0.05 level of significance. The assumptions of normality and homogeneity of variance were analyzed using Shapiro-Wilk, and Levene's tests, respectively, and data were Square Root-transformed for normality before analysis. All analysis listed above were conducted using SAS version 9.4 (SAS Institute, Cary, NC).

\section{Results}

\subsection{D. glabrata Population and Damage at Pre-and Post-Insecticide Application}

Efficacy of the four OMRI-approved insecticides, Azatin ${ }^{\circledR} \mathrm{O}$, PyGanic $^{\circledR}$, Entrust $^{\circledR}$ and Ecotec ${ }^{\circledR}$ in reducing the $D$. glabrata population and the associated leaf damage for the two seasons are shown in Figures 1 and 2 (2017) and Figures 3 and 4 (2018). In 2017, Green Callaloo, the most susceptible variety, received the number of insecticide treatments as indicated: Azatin ${ }^{\circledR} \mathrm{O}$ was sprayed 5x; Ecotec $^{\circledR}=3 \mathrm{x}$; PyGanic ${ }^{\circledR}$ and Entrust ${ }^{\circledR}=2 \mathrm{x}$ (Figure 1). The interval between applications was longest with Pyganic. 

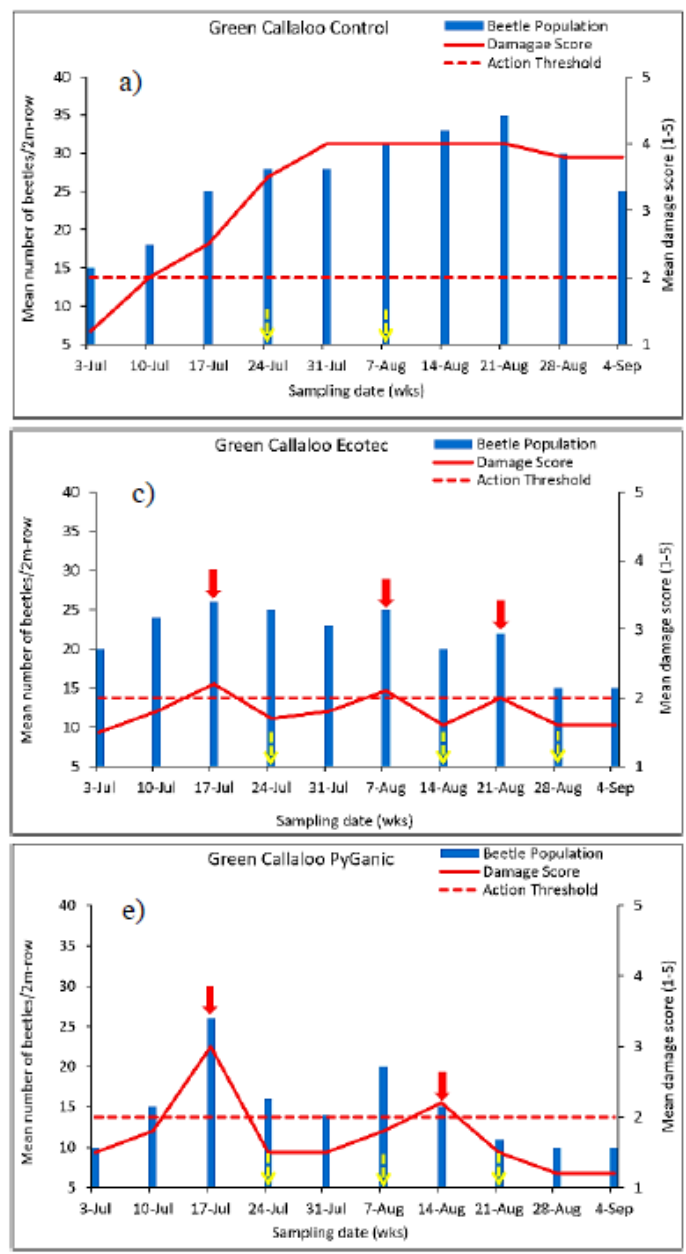

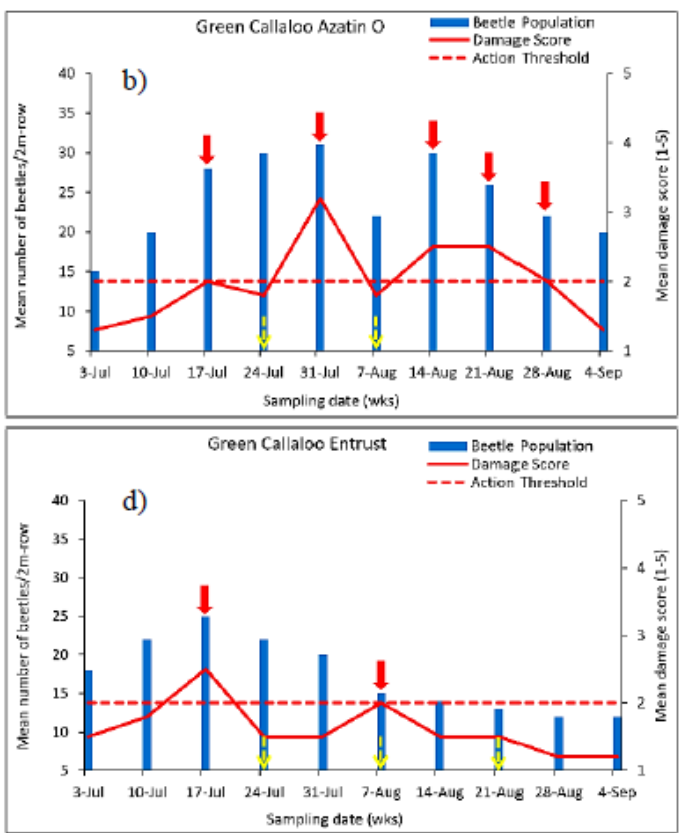

Sampline date (wiks)

Figure 1. Weekly mean ( \pm SE) of $D$. glabrata population and corresponding damage (i.e., scores: $1=0-20 \%, 2$ $=>20-140 \%, 3=>40-60 \%, 4=>60-80 \%$ and $5=>80-100 \%$ leaf damage) on Green Callaloo amaranth varieties at pre- and post- insecticide application in 2017. Vertical yellow arrows along baseline indicate harvest times and red arrows show insecticide application

Molten Fire variety was excluded from all analysis due to non-attainment of the action threshold score of 2 (i.e. > $20-40 \%$ leaf damage) required for insecticide application. The population of D. glabrata counts differed significantly (Fisher's critical value $(\mathrm{F})=3.40$, degrees of freedom $(\mathrm{df})=4,15$; level of significance $(P)=$ 0.0445 , blocking effect: $\mathrm{F}=5.40, \mathrm{df}=3,15 ; P<0.0001)$ among the insecticide treatments. Azatin ${ }^{\circledR} \mathrm{O}(23.0 \pm$ $1.1 / 2 \mathrm{~m}$-row) and the control (water spray) $(20.0 \pm 1.5 / 2 \mathrm{~m}$-row) recorded the highest $D$. glabrata population while Entrust ${ }^{\circledR}\left(10.0 \pm 1.2 / 2 \mathrm{~m}\right.$-row) and PyGanic ${ }^{\circledR}$ treatments $(10.0 \pm 1.3 / 2 \mathrm{~m}$-row $)$ on the other hand, recorded the lowest $D$. glabrata counts. In addition, significant difference $(\mathrm{F}=26.06, \mathrm{df}=4,15 ; P<0.0001$, blocking effect: $\mathrm{F}=4.40, \mathrm{df}=3,15 ; P=0.0134$ ) in herbivory (leaf damage) was observed in the insecticide treatments within the Green Callaloo amaranth variety, but not with Molten Fire. Low herbivory (score of below 2 signifying $0-20 \%$ leaf damage) was associated with Entrust ${ }^{\circledR}$ and PyGanic ${ }^{\circledR}$ treatments while the remaining insecticide treatments and the control had high leaf feeding damage (Figure 2). 


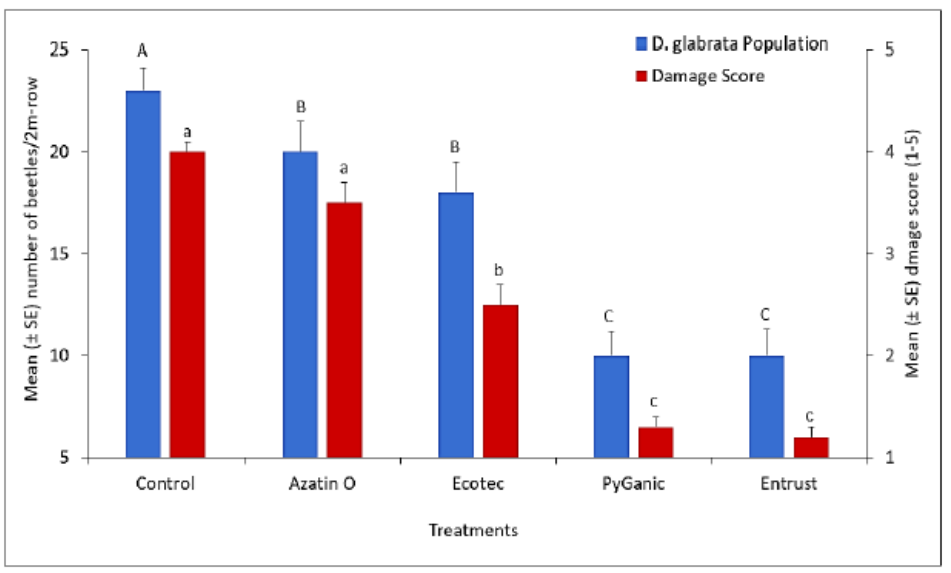

Figure 2. D. glabrata population and level of herbivory on Green Callaloo amaranth variety post insecticide application, 2017. Different uppercase letters on bars indicate significant difference in D. glabrata population between insecticide treatments; different lowercase letters above bars indicate significant difference in leaf damage between insecticide treatments (Fisher's LSD; $P<0.05$ )

In 2018, Green Callaloo and Red Leaf varieties received all the insecticide treatments at different intervals: Azatin ${ }^{\circledR} \mathrm{O}$ was sprayed 5x; Ecotec ${ }^{\circledR}=3 \mathrm{x}$; PyGanic ${ }^{\circledR}$ and Entrust $^{\circledR}=2 \mathrm{x}$, respectively (Figure 3). Molten Fire and Hopi Red-Dye did not receive any insecticide treatment since they did not attain the required treatment action threshold. They are therefore omitted from the figure.
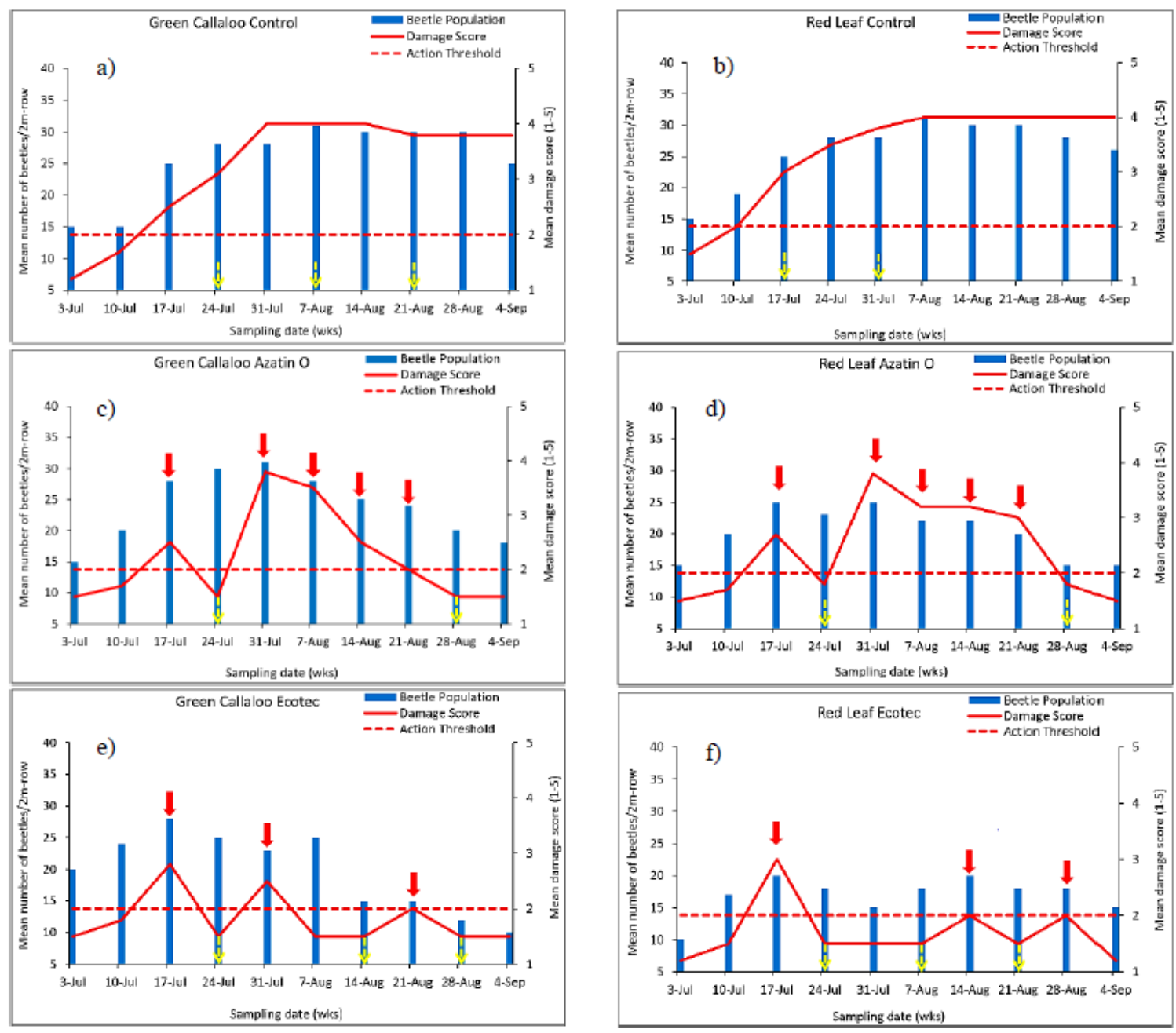

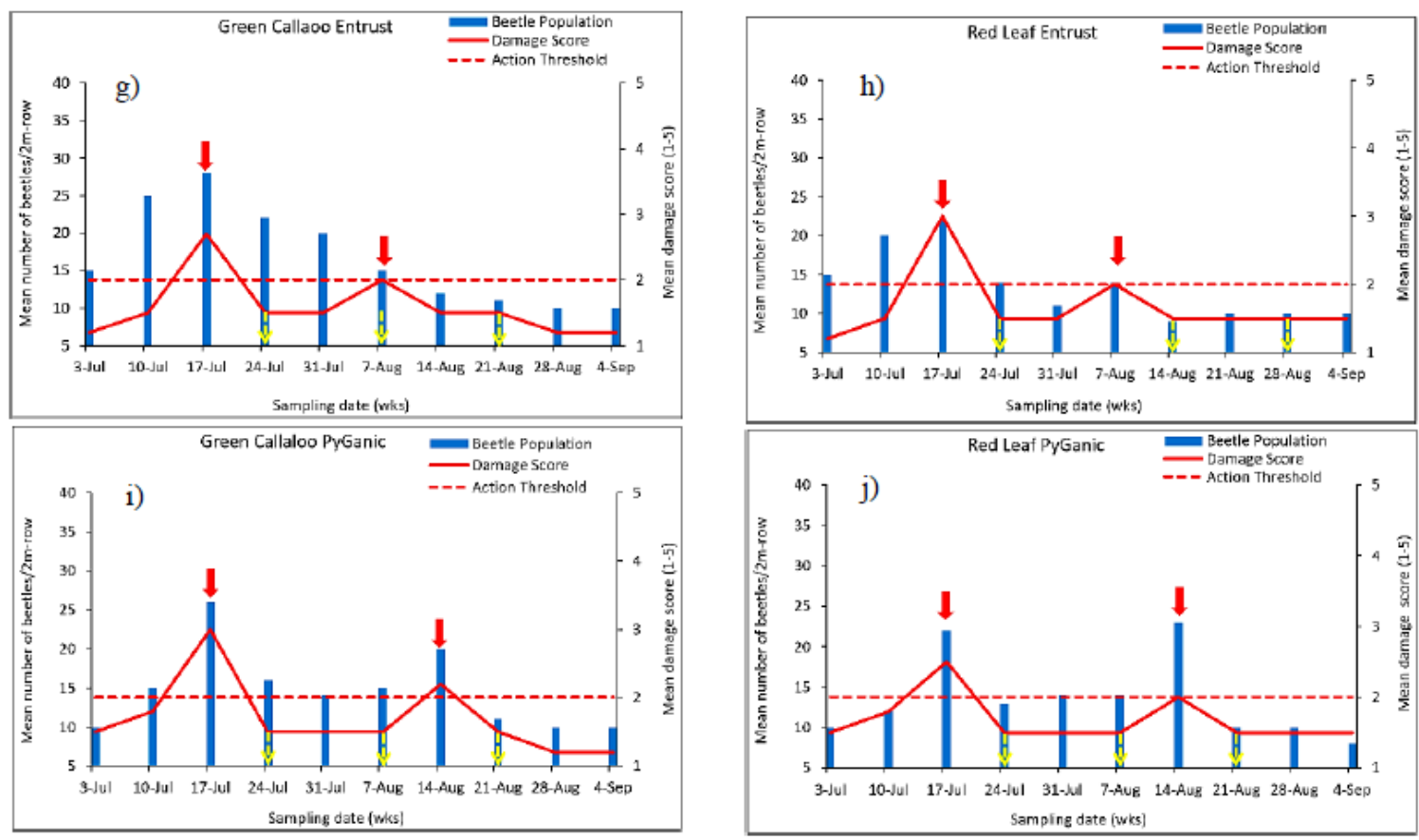

Figure 3. Weekly mean $( \pm \mathrm{SE})$ of $D$. glabrata population and corresponding damage (i.e., scores: $1=0-20 \%, 2$ $=>20-40 \%, 3=>40-60 \%, 4=>60-80 \%$ and $5=>80-100 \%$ leaf damage) on Green Callaloo and Red Leaf amaranth varieties at pre- and post- label rate insecticide application in 2018. Vertical yellow arrows along baseline represent harvest times and red arrows indicate insecticide application

The efficacy of the tested insecticides differed significantly [(i) D. glabrata population on Green Callaloo: $\mathrm{F}=$ 17.19, $\mathrm{df}=4,15 ; P<0.0001$, blocking effect: $\mathrm{F}=8.20, \mathrm{df}=3,15 ; P=0.0371$, (ii) Red Leaf: $\mathrm{F}=10.19, \mathrm{df}=4$, $15 ; P=0.0003$, blocking effect: $\mathrm{F}=7.40, \mathrm{df}=3,15 ; P=0.0285]$ under field conditions between the two amaranth varieties but the interaction between the insecticide treatments and varieties was not significant $(\mathrm{F}=$ $0.37, \mathrm{df}=8,30 ; P=0.8247)$. Entrust ${ }^{\circledR}$ and PyGanic ${ }^{\circledR}$ treatments performed extremely well in 2018 recording the lowest $D$. glabrata population followed by $\operatorname{Ecotec}^{\circledR}$ (Figure 4 (a) and (b)). 

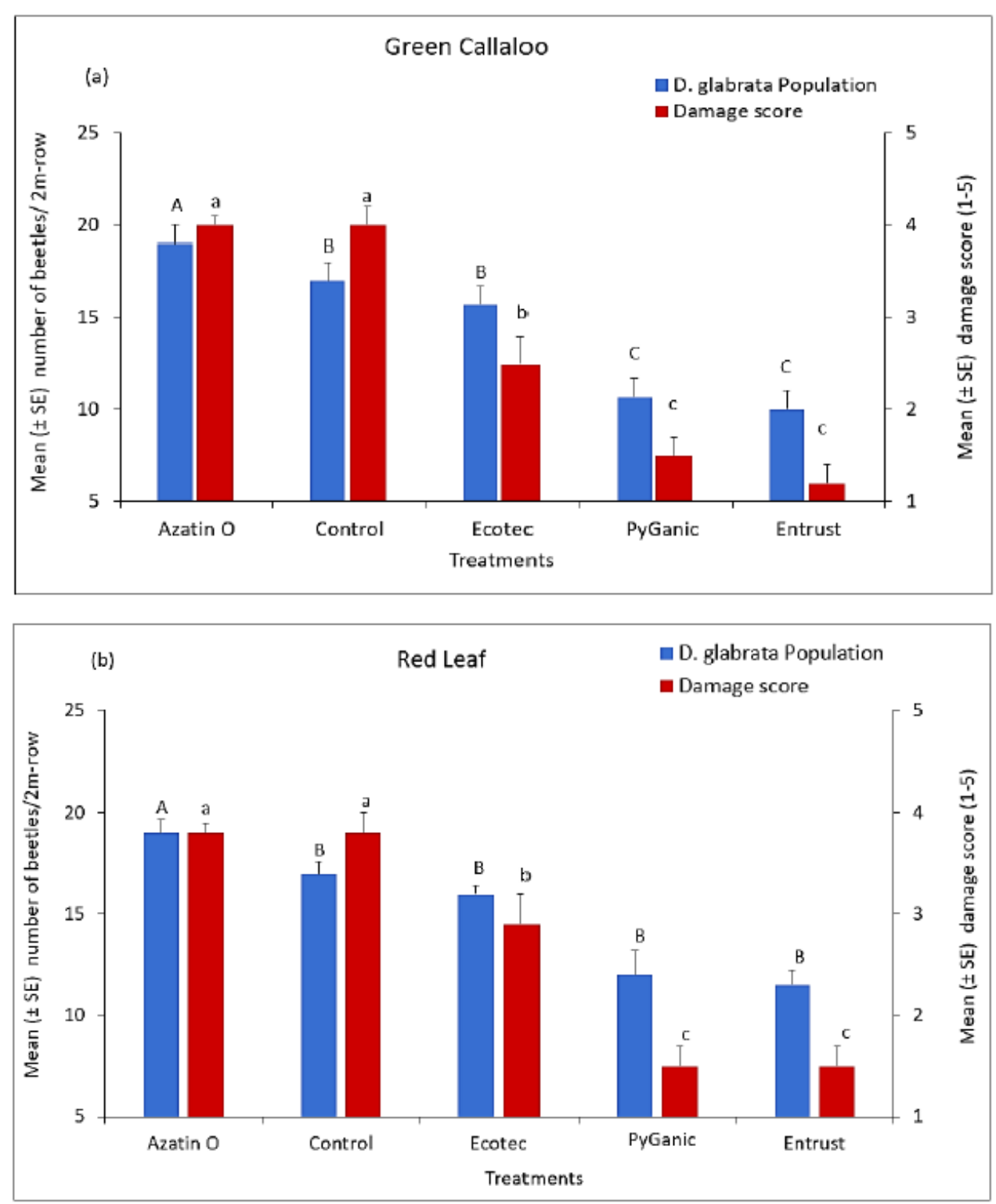

Figure 4. D. glabrata population and level of herbivory post insecticide application. Different uppercase letters on bars indicate significant difference in D. glabrata population between insecticide treatments, while different lowercase letters above bars indicate significant difference in herbivory between insecticide treatments (Fisher's

LSD; $P<0.05)$

Azatin ${ }^{\circledR}$ O performed poorly, recording the highest $D$. glabrata population. Significant differences were observed in the level of damage [(i) Green Callaloo: $\mathrm{F}=26.06, \mathrm{df}=4,15 ; P<0.0001$, blocking effect: $\mathrm{F}=16.16, \mathrm{df}=3$, 15; $P<0.0001$, (ii) Red Leaf: $\mathrm{F}=42.04$, df $=4,15 ; P<0.0001$, blocking effect: $\mathrm{F}=23.26$, df $=3,15 ; P<$ $0.0001]$ for the insecticide treatments between the amaranth varieties. No significant interaction $(\mathrm{F}=15.22, \mathrm{df}=$ 8,$30 ; P=0.0850$ ) was observed between the insecticide treatments and amaranth varieties in 2018. Entrust ${ }^{\circledR}$ and PyGanic ${ }^{\circledR}$ treatments recorded about $80 \%$ lower damage compared to Azatin ${ }^{\circledR} \mathrm{O}$ and the control (Figure 4).

\subsection{Amaranthus spp. Fresh Leaf Yield}

Marketable yield of the amaranth varieties differed significantly (Green Callaloo: $\mathrm{F}=7.07, \mathrm{df}=4,15 ; P=$ 0.0036, blocking effect: $\mathrm{F}=2.06, \mathrm{df}=3,15 ; P<0.0001$ ) in 2017 and in 2018 [(i)Green Callaloo: $\mathrm{F}=3.99, \mathrm{df}=$ 4, 15; $P=0.0277$, blocking effect: $\mathrm{F}=4.35, \mathrm{df}=3,15 ; P<0.0001$, (ii) Red Leaf: $\mathrm{F}=6.12$, df $=4,15 ; P=$ 0.0064 , blocking effect: $\mathrm{F}=5.04, \mathrm{df}=3,15 ; P<0.0001]$ among the insecticide treatments. Green Callaloo treated with Entrust ${ }^{\circledR}$ and Azatin ${ }^{\circledR} \mathrm{O}$ recorded the highest and lowest fresh leaf yield, respectively in 2017 while 
PyGanic ${ }^{\circledR}$ treated Green Callaloo amaranth had the highest fresh leaf yield in 2018 (Table 1). No significant interaction $(\mathrm{F}=8.22, \mathrm{df}=8,30 ; P=0.0650)$ was observed between the insecticide treatments and amaranth varieties in 2018. Hopi Red-Dye amaranth variety recorded the lowest fresh leaf yield; it did not receive insecticide treatment since it never attained the treatment threshold.

Table 1. Marketable fresh leaf yield (mean $\pm \mathrm{SE}$ ) of two amaranth varieties under different insecticide treatments and two $(*)$ with no insecticides applied

\begin{tabular}{|c|c|c|c|c|c|c|}
\hline \multirow[t]{2}{*}{$\begin{array}{l}\text { Insecticide } \\
\text { Treatments }\end{array}$} & \multicolumn{3}{|c|}{$\begin{array}{l}\text { Average fresh leaf yield of amaranth } \\
\text { varieties }(\mathrm{kg} / \mathrm{ha})^{\dagger}(2017)\end{array}$} & \multicolumn{3}{|c|}{$\begin{array}{l}\text { Average fresh leaf yield of amaranth } \\
\text { varieties }(\mathrm{kg} / \mathrm{ha})^{\dagger}(\mathbf{2 0 1 8})\end{array}$} \\
\hline & Green Callaloo & Molten Fire* & Green Callaloo & Red Leaf & Molten Fire* & Hopi Red-Dye* \\
\hline & $5555.6 \pm 484.3^{\mathrm{a}} \mathrm{A}$ & $5500.0 \pm 847.4$ & $3958.3 \pm 550.1^{\mathrm{b}} \mathrm{B}$ & $3641.7 \pm 873.8^{\mathrm{bc}}$ & $5033.3 \pm 1039.4$ & $5458.3 \pm 103.4$ \\
\hline PyGanic ${ }^{\circledR}$ & $8166.7 \pm 577.4^{\mathrm{b}} \mathrm{A}$ & $6072.2 \pm 980.1$ & $69.3^{\mathrm{a}} \mathrm{B}$ & $6500.0 \pm 726.5^{\mathrm{a}}$ & $2500.0 \pm 180.0$ & 2125.0 \\
\hline Azatin $^{\circledR} \mathrm{O}$ & $4444.4 \pm 364.3^{\mathrm{b}} \mathrm{A}$ & $5111.1 \pm 400.6$ & $2250.0 \pm 259.1^{\mathrm{b}} \mathrm{B}$ & $1916.7 \pm 107.6^{c}$ & $4500.0 \pm 833.3$ & $2916.7 \pm 198.4$ \\
\hline Entrust $^{\circledR}$ & $10464.1 \pm 2555.8^{\mathrm{a}} \mathrm{A}$ & $5927.8 \pm 396.3$ & $7416.7 \pm 529.2^{\mathrm{a}} B$ & $6208.3 \pm 528.7^{\mathrm{ab}}$ & $4666.7 \pm 781.7$ & $3625.0 \pm 79.8$ \\
\hline Ecotec $^{\circledR}$ Plus & $9025.0 \pm 2292.8^{\mathrm{a}} \mathrm{A}$ & $5533.3 \pm 1040.5$ & $5917.0 \pm 308.1^{\mathrm{ab}} \mathrm{B}$ & $4958.3 \pm 136.1^{\mathrm{bc}}$ & $3125.0 \pm 248.8$ & $4958.3 \pm 356.0$ \\
\hline
\end{tabular}

Means followed by the same upper-case letters (between rows) or lower-case letter (within columns) are not significantly different at $P<$ 0.05 using Fisher's LSD $(P<0.05)$

* Molten Fire and (2017 and 2018) and Hopi Red Dye (2018) did not receive any insecticide treatments because their damage level was below the pre-set action threshold for pesticide application.

${ }^{\dagger}$ Average fresh leaf yield values extrapolated from 8 plants per plot

\section{Discussion}

\subsection{Effects of Biorational Insecticides on D. glabrata Population and Herbivory on Amaranthus spp.}

The use of synthetic insecticides to suppress insect pests over the decades has led to phenomenal protection of crops from total loss, increase in crop yields, improvement in food security, sustained agricultural livelihoods in addition to improvements in growers' income (McLeod, Diaz, \& Johnson, 2002; Schneider, Smagghe, Pineda, \& Vinuela, 2004; Balusu \& Fadamiro, 2012). Despite these achievements, their use has become a serious global concern due to the high toxicity to humans and a disruption in ecosystem processes (Showler, Greenberg, \& Arnason, 2004; Overall, 2008). Biorational insecticides cause less environmental harm while providing effective management of crop pests (Showler et al. 2004; Overall, 2008; Leskey, Lee, Short, \& Wright, 2012; Laznik \& Trdan, 2017; Iwuagwu et al., 2019; Muralikrishna et al., 2019). The results from this study confirm the effect of OMRI-approved insecticides in the management of D. glabrata. All the insecticides used suppressed $D$. glabrata population to different degrees; Azatin ${ }^{\circledR} \mathrm{O}$ treatments had the shortest application interval (higher frequency), requiring weekly applications in order to suppress beetle populations and keep the associated damage below the action threshold. Despite five applications in both 2017 and 2018, this was hardly achieved. And considering the cost of the product (\$225.0-290.0/32fl. oz.) and the economic status of many small growers, use of Azatin O will become financially prohibitive for many limited resource growers and an unsatisfactory outcome (Iwuagwu et al., 2019; Muralikrishna et al., 2019). The manufacturer's label indicates that Azatin ${ }^{\circledR} \mathrm{O}$ is more effective in suppressing larval or nymphal insect stages (not adults) which may, at least in part, explain the poor performance recorded for adults in this study. The mode of action is either as an antifeedant, or by inhibition of molting through interferance with protein synthesis and the regulation of lipid metabolism; this subsequently leads to death (Huang, Shi, Chen, \& Du, 2007).

The lowest D. glabrata populations were obtained with Entrust ${ }^{\circledR}$ and PyGanic ${ }^{\circledR}$ treatments. Both insecticides were applied 2x in 2017 and 2018 with $\mathrm{PyGanic}^{\circledR}$ treatment recording the longest spray interval. Although Pyrethrin (active ingredient in PyGanic ${ }^{\circledR}$ ) breaks down easily in high temperatures (Bonnie, Blackman, \& Faber, 2004) we ensured a longer duration of toxicity by applying the insecticide during the early morning hours (between 7am-9am). Upon application of PyGanic ${ }^{\circledR}$ D. glabrata adults were observed to immediately drop off amaranth plants and without recolonizing. This eventually resulted in their death. The rapid knock-down is a recognized mode of action of this insecticide group (Isman, 2006; Balusu \& Famadiro, 2012). It appears obvious that this must have reduced feeding by D. glabrata hence the low herbivory observed in the PyGanic ${ }^{\circledR}$ treatments. The functional physiological processes involved in this scenario are known to include blockage of the voltage-gated sodium channels in the nerve axons of the beetle causing a decrease in excitability and fatigue resulting in subsequent death (Burt \& Goodchild, 1971). The above finding is consistent with the findings of Cavanagh, Hazzard and Brown (2011) and Balusu and Famadiro (2012) who observed significant reductions in 
Leptinotarsa decemlineata Say population on eggplant and Microtheca ochroloma Stål on crucifers, respectively, after application of PyGanic ${ }^{\circledR}$.

Following foliar application of Entrust ${ }^{\circledR}$, two things were observed, (i) similar behavior of D. glabrata as when PyGanic ${ }^{\circledR}$ was applied, and (ii) reduced herbivory. Possible explanations are (a) Entrust ${ }^{\circledR}$ is neurotoxic upon contact causing paralysis, inactivity and eventually death of the beetles (Thompson et al., 2000; Igrc et al., 2006), (b) Entrust ${ }^{\circledR}$ (active ingredient spinosad) penetrates the leaf lamina and controls the insects upon contact as well as those feeding on the lower side of the leaf due to excellent trans-laminar activity (Thompson et al., 2000; Williams, Valle, \& Viñuela, 2003). This second point may also account for longer spray interval application of Entrust $^{\circledR}$. Regardless, both Entrust ${ }^{\circledR}$ and PyGanic ${ }^{\circledR}$ were highly effective in controlling D. glabrata populations on the Amaranthus spp. However, given the price differential between the two products (Entrust ${ }^{\circledR}$ : $\$ 550.0-580.0 / 32 \mathrm{fl}$. Oz; PyGanic ${ }^{\circledR}: \$ 50-60 / 32 \mathrm{fl}$. oz) careful financial considerations would have to be made before deciding which of the two products is better suited to individual circumstances.

The 3x application of Ecotec ${ }^{\circledR}$, sometimes bi-weekly, resulted in lower D. glabrata populations and damage in comparison to the water control and Azatin ${ }^{\circledR} \mathrm{O}$. This may, at least in part, be a result of its nuerotoxic effects that kill the insects (Seaman, Lange, \& Shelton, 2014a). In addition, its individual components (peppermints, rosemary, and geraniol) have low volatility oils that cause high repellency and/or antifeedant effects that may also be detrimental to D. glabrata (Seaman, Lange, \& Shelton, 2014b). Ecotec ${ }^{\circledR}$ (32fl. oz.) is relatively inexpensive, ranging between $\$ 26.0$ and $\$ 30.0$. However, in the event of a high infestation of D. glabrata as occurs with the addition of leaf compost mulch (Vorsah et al., 2020), Ecotec ${ }^{\circledR}$ may not be the insecticide of choice for the control of D. glabrata due to the slow rate at which it inflicts mortality (Seaman et al., 2014a).

As stated earlier, straw mulch was used as weed suppressant in the 2-year study. It is interesting to note apart from its ability to control weeds, the straw mulch, like other organic mulches, may have contributed to the surge in D. glabrata population in providing a microclimate which promoted beetle growth and development (Vorsah et al., 2020). This is more evident in the unsprayed control which recorded a high weekly beetle population and damage (Figure 1 and 3).

All the four insecticides evaluated in this study have been reported to have varied impact on beneficial insects (e.g. parasitoids, pollinators, predators) and other aquatic invertebrates (Simmonds, Manlove, Blaney, \& Khambay, 2002; Williams, Valle, \& Viñuela, 2003; Charleston, Kfir, Dicke, \& Vet, 2005; Turchen, Golin, Butnariu, Guedes, \& Pereira, 2016). The study, however, did not evaluate the effects of these insecticides on beneficials.

\subsection{Effects of Biorational Insecticides on the Fresh Leaf Yield of Amaranthus spp.}

The results of our research showed that higher amaranth fresh leaf yield was recorded in Green Callaloo and Molten Fire in 2017 than in 2018 (Table 1). This may be related to extreme lodging of some plants that occurred in 2018 when inclement weather conditions (high rainfall and wind) prevailed in the study area. That notwithstanding, the results of our study reaffirm that use of biorational insecticides has the potential to impact amaranth yield (Laznik \& Trdan, 2017; Balusu \& Fadamiro, 2012). PyGanic ${ }^{\circledR}$; Entrust ${ }^{\circledR}$ and Ecotec ${ }^{\circledR}$-treated amaranth recorded higher yields in both 2017 and 2018 than did Azatin ${ }^{\circledR} \mathrm{O}$ and the unsprayed control. This seems to be because these insecticides $\left(\right.$ PyGanic $^{\circledR}$, Entrust $^{\circledR}$ and Ecotec $^{\circledR}$ ): (i) elicited more D. glabrata mortality through direct contact or ingesting sprayed leaves (Thompson et al., 2000; Igrc et al., 2006), (ii) they possessed antifeedant and/or repellent properties which resulted in low herbivory (Toscano, Yoshida, \& Henneberry, 1997; Overall, 2008). Irrespective of the insecticide treatments, the observed differences in yield among the amaranth varieties may be also attributable to differences in their genetic and phenotypic traits, and possibly other variables (Akond, Islam, \& Wang, 2013a; Akond, Islam, \& Wang, 2013b; Vorsah et al., 2020). Finally, all insecticides used in this study have a zero to 1day pre-harvest interval (PHI) making them reasonably safe. It should also be noted that in general, harvested leaves from untreated plots of the highly susceptible varieties such as Green Callaloo were very heavily damaged and would therefore carry very low market value, despite the high yields.

\section{Conclusion}

The OMRI-approved insecticides used in this study have great potential for the management of D. glabrata in organic production of amaranth greens. Entrust and PyGanic ${ }^{\circledR}$ proved to be especially effective. Good quality fresh leaf yields of amaranth are possible with these two insecticides, but this would entail growers learning to recognize when to apply them. Calendar applications may be popular with some growers, but these would make production uneconomical as OMRI-approved insecticides are generally expensive. If cost is prohibitive, Ecotec ${ }^{\circledR}$ may be a safer alternative as it gave good fresh leaf yield compared to Azatin ${ }^{\circledR} \mathrm{O}$ and the control. 
Insecticides should be regarded as only one tool in the toolbox of sustainable pest management. Other measures such as resistant varieties (two of the varieties in this study did not require insecticide treatment) are recommended, but this will depend on consumer preferences for different varieties. In addition, the use of leaf compost and wheat straw mulch is not recommended as these have been shown to provide an ideal environment for the buildup of $D$. glabrata populations (Vorsah et al., 2020). As a precaution regarding the likely over-use of these products, many insect pests have been reported to exhibit resistance to Spinosad and Pyrethrin in conventional production systems (Wei, Appel, Moar, \& Liu, 2001; Sayyed, Omar, \& Wright, 2004), possibly from over-use. To avert the above challenge, rotation of the highly effective insecticides; Entrust ${ }^{\circledR}$, PyGanic ${ }^{\circledR}$, and $\mathrm{Ecotec}^{\circledR}$ is recommended for use in organic production of Amaranthus spp. (Schneider et al., 2004). The use of a treatment threshold was introduced into the study to minimize the occurrence of insecticide resistance. Since many organic growers are expanding into other production platforms such as high tunnels, greenhouses and others for vegetable production, further studies would be required to determine efficacy of these insecticides under those conditions (Balusu \& Fadamiro, 2012). In addition, there are many other biorational insecticides we did not evaluate in our study. These leaves a lot of room for further evaluation to expand the scope of options for use by growers.

\section{Acknowledgments}

This research was funded by the USDA-NIFA Evans Allen Program, Grant NC.X304-5-17-130-1. Author contributions: conceptualization, L.E.J., and B.N.D.; methodology, L.E.J., and B.N.D.; formal analysis, R.V.V., H.S., and L.E.J.; investigation, R.V.V., and L.E.J.; resources, L.E.J.; data curation, R.V.V., H.S., and L.E.J.; writing — original draft preparation, R.V.V; writing — review and editing, L.E.J., B.N.D., and H.S.; supervision, L.E.J., and B.N.D.; project administration, L.E.J.; funding acquisition, L.E.J. and B.N.D. We also acknowledge the assistance of the staff in the IPM Laboratory at NCA\&TSU. We are also grateful to the Agricultural Research Program at NC A\&T State University and assistance from Nicholas Mangili, the Manager of Guilford College Farm.

\section{References}

Akond, M., Islam, S., \& Wang, X. (2013a). Characterisation of biomass traits and cell wallcomponents among diverse accessions of Amaranthaceae. Journal of Applied Phytotechnology and Environmental Sanitation, 2, 37-45.

Akond, M., Islam, S., \& Wang, X. (2013b). Genotypic variation for biomass traits and cell wall components among 35 diverse accessions of Amaranthaceae family. Journal of Applied Phytotechnology in Environmental Sanitation, 2, 37-45.

Baker, B. P., Green, T. A., Cooley, D., Futrell, S., Garling, L., Gershuny, G., ... Young. S. L. (2015). Organic agriculture and integrated pest management: A synergistic partnership to improve sustainable agriculture and food systems. p. 40.

Balusu, R. R., \& Fadamiro, H. Y. (2012). Evaluation of organically acceptable insecticides as stand-alone treatments and in rotation for managing yellow-margined leaf beetle, Microtheca ochroloma (Coleoptera: Chrysomelidae), in organic crucifer production. Pest Management Science, 68, 573-579. https://doi.org/10.1002/ps.2297

Blake, D. H. (1933). Revision of the beetles of the genus Disonycha occurring in America north of Mexico. Proceedings of the United States National Museum, 82, 1-66. https://doi.org/10.5479/si.00963801.82-2969.1

Blake, D. H. (1955). Revision of the vittate species of the chrysomelid beetle genus Disonycha from the Americas south of the United States. Proceedings of the United States National Museum, 104, 1-86. https://doi.org/10.5479/si.00963801.104-3338.1

Bonnie L. A., Blackman, J. A., \& Faber, H. (2004). The degradation of the natural pyrethrins in crop storage. Journal of Agricultural and Food Chemistry, 52, 280-287. https://doi.org/10.1021/jf0304425

Brenner, D., Baltensperger, D., Kulakow, P., Lehmann, J., Myers, R., Slabbert, M., \& Sleugh, B. (2000). Genetic resources and breeding of amaranthus. Plant Breeding Reviews, 19, 227-285. https://doi.org/10.1002/9780470650172.ch7

Burt, P. E., \& Goodchild, R. E. (1971). The site of action of pyrethrin I in the nervous system of the cockroach, Periplaneta americana. Entomologia Experimentalis et Applicata, 14, 179-189.

https://doi.org/10.1111/j.1570-7458.1971.tb00155.x 
Cavanagh, A., Hazzard, R., \& Brown, A. (2011). Efficacy of three OMRI listed materials, alone and in combination, for control of Colorado potato beetle in eggplant, 2009. Arthropod Management Tests, 36, E31. https://doi.org/10.4182/amt.2011.E31

Charleston, D. S., Kfir, R., Dicke, M., \& Vet, L. E. M. (2005). Impact of botanical pesticides derived from Melia azedarach and Azadirachta indica on the biology of two parasitoid species of the diamondback moth. Biological Control, 33, 131-142. https://doi.org/10.1016/j.biocontrol.2005.02.007

Cordero, R., Kuhar, T., Speese, J., \& Barlow, V. (2005). Evaluation of insecticides in collards, 2004. Arthropod Management Tests, 30, E22-E22. http://dio.org/10.1093/amt/30.1.E22

Ezeh, A. E., Ogbedegbe, A. B. O., \& Ogbedegbe, S. A. (2015). Insect pest occurrence on cultivated Amaranthus Spp. in Benin City, Edo State, Nigeria. Journal of Applied Sciences and Environmental Management, 19, 335-339. https://doi.org/10.4314/jasem.v19i2.22

Flanery, M., Sintim, H., Dingha, B., \& Jackai, L. (2016). Laboratory evaluation of biorational and low risk insecticides and their mixtures for management of Diamondback moth larvae. Journal of Agricultural Science and Technology, A. 6. http://dio.org/10.17265/2161-6256/2016.02.001

Hemenway, R., \& Whitcomb, W. H. (1968). The life history of Disonycha glabrata (Coleoptera: Chrysomelidae). Journal of the Kansas Entomological Society, 41, 174-178.

Huang, Z., Shi, P., Chen, G. \& Du, J. (2007). Effects of azadirachtin on hemolymph protein expression in Ostrinia furnacalis (Lepidoptera: Crambidae). Annals of The Entomological Society of America Journal, 100, 245-250. https://doi.org/10.1603/0013-8746(2007)100[245:EOAOHP]2.0.CO;2

Igrc, B. J., Bazok, R., Bezjak, S., Culjak T. G., \& Barcic, J. (2006). Combinations of several insecticides used for integrated control of Colorado potato beetle (Leptinotarsa decemlineata Say., Coleoptera: Chrysomelidae). Journal of Pest Science, 79, 223-232. https://doi.org/10.1007/s10340-006-0138-5

Isman, M. B. (2006) Botanical insecticides, deterrents, and repellents in modern agriculture and an increasingly regulated world. Annual Review of Entomology, 51, 45-66.

https://doi.org/10.1146/annurev.ento.51.110104.151146

Iwuagwu, M. O, Ogbonna, N. C., \& Okechukwu, U. H. (2019). Insecticidal effects of some plant leaf extracts in the control of insect field pests of Amaranthus hybridus L. International Journal of Plant Science and Horticulture, 1, 71-79. https://doi.org/10.36811/ijpsh.2019.110008

Janssen, F., Pauly, A., Rombouts, I., Jansens, K. A. J., Deleu, J. L., \& Delcour, J. A. (2017). Proteins of amaranth (Amaranthus spp.), buckwheat (Fagopyrum spp.), and quinoa (Chenopodium spp.): A food science and technology perspective. Comprehensive Reviews in Food Science and Food Safety, 16, 39-58. https://doi.org/10.1111/1541-4337.12240

Korrat, E. E. E., Abdelmonem, A. E., Helalia, A. A. R., \& Khalifa, H. M. S. (2012). Toxicological study of some conventional and nonconventional insecticides and their mixtures against cotton leaf worm, Spodoptera littoralis (Boisd.) (Lepidoptera: Noectudae). Annals of Agricultural Sciences, 57, 145-152. https://doi.org/10.5539/sar.v6n2p13

Laznik, Z., \& Trdan, S. (2017). Field testing of efficacy of three environmentally friendly insecticides against Colorado potato beetle (Leptinotarsa Decemlineata [Say], Coleoptera, Chrysomelidae) on potato: Evaluation of the effect on yield. Sustainable Agriculture Research, 6, 13-20. https://doi.org/10.5539/sar.v6n2p13

Leskey, T. C., Lee D. H., Short, B. D., \& Wright, S. E. (2012). Impact of insecticides on the invasive Halyomorpha halys (Hemiptera: Pentatomidae): Analysis of insecticide lethality. Journal of Economic Entomology, 105, 1726-35. https://doi.org/10.1603/EC12096

McLeod, P., Diaz, F. J., \& Johnson, D. T. (2002). Toxicity, persistence, and efficacy of Spinosad, chlorfenapyr, and thiamethoxam on eggplant when applied against the eggplant flea beetle (Coleoptera: Chrysomelidae). Journal of Economic Entomology, 95, 331-335. https://doi.org/10.1603/0022-0493-95.2.331

Muralikrishna, P., Mathew, T., Paul, A., \& Nithya, P. R. (2019). Evaluation of bio-efficacy of new generation insecticides, botanicals and microbial insecticides on leaf Webber of amaranth. Journal of Entomology and Zoology Studies, 7, 516-520.

Niveyro, S. L., Mortensen, A. G., Fomsgaard, I., \& S., Salvo, A. (2013). Differences among five amaranth varieties (Amaranthus spp.) regarding secondary metabolites and foliar herbivory by chewing insects in the 
field. Arthropod Plant Interaction, 7, 235-245. https://doi.org/10.1007/s11829-012-9219-y

Nuessly, G. S. (2005). Evaluation of insecticides for control of Diamondback moth on chinese cabbage, 2005. Arthropod Management Tests, 31, E6-E6. http://dio.org/10.1093/amt/31.1.e6

OTA. (2015). OTA's 2015 US families organic attitudes and beliefs study. Washington D.C.: Organic Trade Association. Retrieved from https://ota.com/what-ota-does/market-analysis/consumer-attitudesand-beliefs-study

Overall, L. M. (2008). Evaluation of organic insecticides to control harlequin bug, Murgantia histrionica (hahn), and yellow-margined Leaf beetle, Microtheca ochroloma stål, On leafy greens (Master's thesis, Oklahoma State University, Oklahoma, United States of America). Retrieved from https://shareok.org/bitstream/handle/11244/9005/Overall_okstate_0664M_2632.pdf?sequence=1

Rastogi, A., \& Shukla, S. (2013). Amaranth: A new millennium crop of nutraceutical values. Critical Reviews in Food Science and Nutrition, 53, 109-125. http://dio.org/10.1080/10408398.2010.517876

Sayyed A. H., Omar, D., \& Wright, D. J. (2004). Genetics of Spinosad resistance in a multi-resistant field-selected population of Plutella xylostella. Pest Management Science, 60, 827-832. https://doi.org/10.1002/ps.869

Schneider, M. I., Smagghe, G., Pineda, S., \& Vinuela, E. (2004). Action of insect growth regulator insecticides and Spinosad on life history parameters and absorption in third-instar larvae of the endoparasitoid Hyposoter didymator. Biological Control, 31, 189-98. https://doi.org/10.1016/j.biocontrol.2004.04.013

Seaman, A., Lange, H., \& Shelton, A. M. (2014a). Crucifer flea beetle control with insecticides allowed for organic production, 2013. Arthropod Management Tests, 39, E62. https://doi.org/10.4182/amt.2014.E62

Seaman, A., Lange, H., \& Shelton, A. M. (2014b). Swede midge control with insecticides allowed for organic production. Arthropod Management Tests, 39, E64. https://doi.org/10.4182/amt.2014.E64

Showler, A. T., Greenberg, S. M. \& Arnason. J. T. (2004). Deterrent effects of four neem-based formulations on gravid female boll weevil (Coleoptera: Curculionidae) feeding and oviposition on cotton squares. Journal of Economic Entomology, 97, 414-421. https://doi.org/10.1093/jee/97.2.414

Simmonds, M. S. J., Manlove, J. D., Blaney, W. M., \& Khambay, B. P. S. (2002). Effects of selected botanical insecticides on the behavior and mortality of the glasshouse whitefly Trialeurodes vaporariorum and the parasitoid Encarsia formosa. Entomologia Experimentalis et Applicata, 102, 39-47. https://doi.org/10.1046/j.1570-7458.2002.00923.x

Sufang, F., Fengzu, Z., Kailin D., Chuanshan Y., Shaowen, L., Pengyue, Z., \& Canping, P. (2013). Spinach or amaranth contains highest residue of metalaxyl, fluazifop-P-butyl, chlorpyrifos, and lambda-cyhalothrin on six leaf vegetables upon open field application. Journal of Agricultural and Food Chemistry, 61, 2039-2044. https://doi.org/10.1021/jf304710u

Thompson, G. D., Dutton, R., \& Sparks, T. C. (2000). Spinosad-a case study: an example from a natural products discovery program. Pest Management Science, 56, 696-702.

https://doi.org/10.1002/1526-4998(200008)56:8<696::AID-PS182>3.0.CO;2-5

Tisler, A. M. (1990). Feeding in the pigweed flea beetle, Disonycha glabrata Fab. (Coleoptera: Chrysomelidae), on Amaranthus retroflexus. Virginia Journal of Science, 41, 243-245.

Toscano, N. C., Yoshida, H. A., \& Henneberry, T. J. (1997). Responses to azadirachtin and pyrethrum by two species of Bemisia (Homoptera: Aleyrodidae). Journal of Economic Entomology, 90, 583-589. https://doi.org/10.1093/jee/90.2.583

Turchen, L. M., Golin, V., Butnariu, A. R., Guedes, R. N., \& Pereira, M. J. (2016). Lethal and sublethal effects of insecticides on the egg parasitoid Telenomus podisi (Hymenoptera: Platygastridae). Journal of Economic Entomology, 109, 84-92. https://doi.org/10.1093/jee/tov273

Viglasky, J., Huska, J., Langova, N., \& Suchomel, J. (2008). Multifunctional use of amaranth phytomass for industry and energy. In G. Libiakova \& A. Gajdosova (Eds.), Amaranth-plant for the future: Proceedings from the 5th international symposium of the European amaranth association (pp. 84-91). Slovak Republic: Institute for Plant Genetics and Biotechnology.

Vorsah, R. V., Dingha, B. N., Gyawaly, S., Fremah, S. A., Sharma, H., Bhowmik, A., ... Jackai, L. E. (2020). Organic mulch increases insect herbivory by the flea beetle species. Disonycha glabrata, on Amaranthus spp. Insects, 11, 162-186. https://doi.org/10.3390/insects 11030162 
Wei Y. P., Appel, A. G., Moar, W. J., \& Liu, N. (2001). Pyrethroid resistance and cross-resistance in the German cockroach, Blattella germanica (L.). Pest Management Science, 57, 1055-1059. https://doi.org/10.1002/ps.383

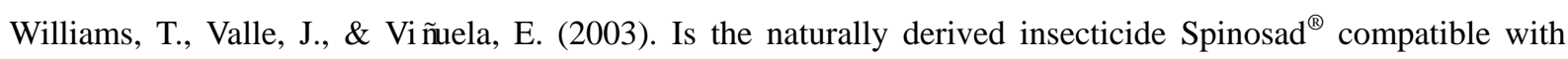
natural enemies? Biocontrol Science and Technology, 13, 459-475. https://doi.org/10.1080/0958315031000140956

Xaba, N. (2014). Use of amaranth as feedstock for bio-ethanol Production. (Master's thesis, North-West University, Potchefstroom, Republic of South Africa). Retrieved from https://pdfs.semanticscholar.org/2442/a2890dab12d3bdf22656ea6da9be8241beba.pdf

\section{Copyrights}

Copyright for this article is retained by the author(s), with first publication rights granted to the journal.

This is an open-access article distributed under the terms and conditions of the Creative Commons Attribution license (http://creativecommons.org/licenses/by/3.0/). 